\title{
Committee Jurisdiction, Congressional Behavior and Policy Outcomes
}

John M. de Figueiredo

Duke University

The Law School

210 Science Drive, Box 90360

Durham, NC 27708

jdefig@duke.edu

May 2011

\begin{abstract}
The literature on congressional committees has largely overlooked the impact of jurisdictional fights on policy proposals and outcomes. This paper develops a theory of how legislators balance the benefits of expanded committee jurisdiction against preferred policy outcomes. It shows why a) senior members and young members in safe districts are most likely to challenge a committee's jurisdiction; b) policy proposals may be initiated off the proposer's ideal point in order to obtain jurisdiction; c) policy outcomes will generally be more moderate with jurisdictional fights than without these turf wars. We empirically investigate these results examining proposed Internet intellectual property protection legislation in the $106^{\text {th }}$ Congress.
\end{abstract}

I would like to thank David King, Romain Wacziarg, and seminar participants at Stanford, MIT and the Berkeley Franco-American Conference on the History, Economics and Law of Intellectual Property Protection for helpful comments. Daniel Braga and Karen Freeman provided excellent for research assistance. 


\section{Committee Jurisdiction, Congressional Behavior and Policy Outcomes}

May 24, 2011

\section{INTRODUCTION}

Congressional committees, as gatekeepers of policy, have enormous power to determine the shape of proposed legislation that reaches the House floor. Scholars have elucidated many reasons why the full membership of Congress might delegate its power to constituent committees. These include that committees offer advantages in cost-effectively obtaining and disseminating information (Krehbiel 1992; Gilligan and Krehbiel 1989), in avoiding cycling in voting and promoting compromise and log-rolling through the politically efficient distribution of rents to constituencies (Weingast and Marshall 1988; Krutz 2001), and encouraging legislators to engage in long-term reputation building to create better information for voters (Kroszner and Strattman 2000). All of these models, however, have an underlying assumption: all jurisdictional boundaries for committees are static and clearly defined for all issues. There is no ambiguity as to the single committee that exercises agenda-setting power over any given bill.

In practice, however, committee jurisdictional boundaries are fluid and ambiguous (Baumgartner et al. 2000). In order to expand their powers, committees attempt to expand jurisdiction to issues on the periphery of other committees' jurisdiction (King 1997). In addition, new issues and technologies come about where no committee is clearly responsible (e.g. nuclear power, computing, Internet) (Oleszek 2001). The contribution of this paper to is to demonstrate that while static boundaries convey monopoly agenda-setting power to the controlling committee that may lead to extreme policy, jurisdictional fights between committees lead not only to strategic behavior by committee members with respect to constituency interests, but can often lead to more moderate policy. 
This paper examines how jurisdictional conflict between U.S. House committees affects policy proposals and policy outcomes. By considering legislators and committees as foresightful and strategic, the paper explores the congressional actors who have incentive to challenge jurisdiction, and how these potential challenges affect the policy positions of the two committees engaged in a jurisdictional turf war. While several previous papers in the area have adroitly described the phenomenon of jurisdictional conflict (Adler and Still 2000; King 1994; Hardin 1998; Oleszek 2001, 2004) they have not linked the process of jurisdictional challenge to its effect on policy outcomes. A small number of other papers have recognized that jurisdiction may affect policy outcomes, but these works have described only the broad contours of this phenomenon (Baumgartner and Jones 1993; Bimber 1996; King 1997) and only tangentially consider its effects. If jurisdictional turf wars result in no differences in policy outcomes than those instances of no jurisdictional conflict, then they are of muted interest as a topic for scholarly study. If jurisdictional turf wars result in large swings in policy outcomes than would otherwise happen, then the literature is quite sparse relative to its policy importance.

The paper begins by developing a theory on jurisdiction with forward-looking committees and legislators. From this theory, hypotheses are generated related to the incentives to introduce new bills and to explain eventual policy proposals and outcomes. We predict the conditions under which compromise will be likely and the nature of this compromise. The paper then examines the theory with multiple pieces of evidence and statistical analyses from proposed legislation offering copyright protection to databases (also now known as Internet intellectual property legislation). In 1999, the House of Representatives encountered a well-known instance of jurisdictional uncertainty and encroachment on that intellectual property issue with the introduction of H.R. 353 and H.R. 1858 covering database copyright protection (Baron 2000; 
Oleszek 2004). With many interest groups acting on each side of the issue, and legislators balancing jurisdictional issues against policy outcomes, the fight between the two bills typifies how jurisdictional battles evolve in Congress.

This paper predicts theoretically, and demonstrates empirically, a number of interesting patterns in the behavior of legislators. First, it shows how committees and legislators balance the benefits from policy outcomes with the benefits and costs associated with challenging jurisdiction over a policy domain. Seeking jurisdiction is not a cost-free exercise, and legislators may be willing to accept a sub-optimal policy in order to obtain future jurisdiction over another agenda. This is not considered in other theories of committee power. Second, the paper argues that those with the greatest incentive to challenge an incumbent jurisdiction will be senior members, and young members who are in safe districts for whom jurisdiction, and the political rents that come with it, is most valuable. Statistical analyses are consistent with this prediction. These results stand in contrast to the current empirical literature, which generally assumes closed-rule, monopoly committee jurisdictions. Finally, policy proposals and outcomes can be significantly affected by the possibility of a challenging committee arising. In particular, the mere threat of introducing a challenger bill can serve to moderate the incumbent's proposal. This is important because it suggests that in many areas, policy outcomes may be the result of an equilibrium strategy that the incumbent committee plays in order to fend off potential challenger committees. Thus, introducing jurisdictional conflict frequently serves to create more moderate policy positions than would occur in a model of monopoly, agenda-setting committee power. Introducing multiple pieces of empirical evidence, we show how this occurs.

In the next section, we offer some background on House committee jurisdictions and develop a simple theoretical perspective that explicates the behavior when two competing bills 
are introduced. Section 3 summarizes the legislative fights over Internet database protection that occurred in the $106^{\text {th }}$ Congress. Section 4 examines each of the hypotheses using both descriptive and statistical evidence. Section 5 concludes.

\section{THE THEORETICAL FRAMEWORK}

\subsection{INSTITUTIONAL DETAIL: THE BILL REFERRAL PROCESS}

The process of bill introduction is extremely detailed and complex. In this section, we provide an overview of how bills are referred to committees. Potential legislation in the House is proposed by representatives in the form of bills. Bills are introduced onto the House floor, and then forwarded to the House Parliamentarian, who refers the bill to a House committee for review, modification, or termination. The House Parliamentarian is an appointee of the Speaker of the House and generally considered an unbiased referrer of bills (King 1997), referring bills probabilistically on the merits to individual committees. ${ }^{1}$

The bill referral process comprises two parts: a codified component and a discretionary component. Rule X of the House Rules allots jurisdiction covering pre-specified topics to certain committees. For example, the Judiciary Committee has formal jurisdiction over "patents, the Patent and Trademark Office, copyrights, and trademarks," and the Commerce Committee has formal jurisdiction over "consumer affairs and consumer protection, interstate and foreign commerce generally." Bills that fit neatly into the subject areas identified by Rule X are allocated by the Parliamentarian to the committees with codified jurisdiction over the issue.

Many bills, however, may not fit cleanly into the subject areas identified in Rule X. Some topics may be at the fringe of the jurisdiction of one committee, other bills may not fit into any jurisdiction. Figure 1 illustrates this with a Venn diagram. Imagine two committees, 1 and 
2 , which have jurisdiction over some subset of issue areas. The span of issues is represented by the box. There are some issues for which there is no committee jurisdiction. This is found in the area between the circles. There are other issues such as $A$ that are at the fringe of one committee's jurisdiction (such as Internet intellectual property protection). This paper is about bills like $A$. It is in these cases that the Parliamentarian may exercise discretion in bill referral.

When there is jurisdictional ambiguity, the Parliamentarian, as surrogate for the Speaker of the House, turns to other factors in determining the recipient committee (King 1997; Oleszek 2004). The first factor is whether the current bill amends a public law over which a committee already has jurisdiction. The second factor is previous bill referral precedents, in a common law sense, as guidance for the current bill. The third factor is committee expertise in the policy area, evidenced by oversight hearings (Talbert et al. 1995), the strategic selection of committee staffers, and joining of special issue caucuses. The fourth factor is bill titles and preambles and matching these subject indicators to committees. The Parliamentarian takes all these factors into account when deciding where the "weight of the bill" resides, and which committee should receive the bill. For these reasons legislators adjust their behavior and the language in their bills, to enhance the probability that a bill will be referred to a particular committee.

\subsection{THEORY}

We begin by considering the preferences of legislators and committees. A formal model is outlined in an electronic appendix. ${ }^{2}$ We make four simplifying assumptions. First, all legislators of a given committee prefer more jurisdiction to less jurisdiction for that committee. ${ }^{3}$ Second, jurisdiction is zero-sum. One committee's gain in jurisdiction is another committee's loss. Third, the members of a committee may have differing incentives to introduce a bill. That 
is, bill introduction is not random, but there is a predictable process (with noise) that gives rise to them. ${ }^{4}$ Finally, the goal of a given legislator is to be re-elected.

With these four assumptions in hand, we can now analyze bill introduction. We begin by considering only two committees and single-committee referral. In the next section, we will examine multiple referrals. Any bill proposed by a legislator has three components of benefit that help the legislator to be reelected and help the committee members gain power. The first component is the benefit of the policy outcome. The second benefit is from legislative jurisdiction. The third is the benefit from oversight jurisdiction. However, policy creation is not free; it comes at a cost to the legislator. We consider each of these factors below.

The first benefit, policy outcomes, has been well-modeled in spatial location models (Snyder 1991, for example). In these models, legislators choose policies that are on or close to the ideal points of the median voter in their constituency. The closer the policy outcome is to the ideal policy of the median voter in their constituencies, the more utility the legislator obtains.

The second benefit is from legislative jurisdiction. Legislative jurisdiction is the right of committee members to create, review, modify, and refer legislation on a given issue to the floor of the House. There are multiple benefits supplied by legislative jurisdiction. First, with legislative jurisdiction, committees can craft legislation close to their own likings, thus obtaining policy benefits. Second, committee members have control over bills they can exploit in logrolling with other committees. Third, committee members can extract informational and financial rents from the constituencies they regulate (Kroszner and Strattman 2000). The benefit to the committee members is assumed to be increasing at a decreasing rate in jurisdiction.

A final type of benefit is oversight jurisdiction. Enacted laws are normally delegated to a surrogate for implementation and interpretation. For example, telecommunications policy is 
frequently delegated to the Federal Communications Commission (FCC). Intellectual property rules are sometimes delegated to the US Patent Office (USPTO), or are sometimes left in the hands of the the federal courts. With each policy that is delegated, there normally is a congressional committee that provides oversight of the agency charged with implementation. So, for example, the Commerce Committee oversees the FCC and the Judiciary Committee oversees the federal courts. In most cases, legislative jurisdiction is coupled with oversight responsibilities, but this does not necessarily have to be the case. ${ }^{5}$ To the extent that the agency can promulgate regulations affecting industry and interest groups, congressional committees with oversight can place pressure (hearings, budgetary) on agencies to administratively to create policy that might have been difficult to implement within the legislative branch.

All of these benefits are not cost-free to the committee members. In order to engage in policy-making, jurisdiction, and oversight matters, members must invest time and effort, which is related to how much expertise the legislator has in the policy area and her facility in crafting legislation (Hall and Wayman 1990). There is heterogeneity in costs across committees, as well as within committees. ${ }^{6}$

Thus, we can summarize the calculation made by an individual legislator. She values (and can trade-off through a rational cost-benefit calculation) policy outcomes that are close to her ideal point, as well as (against) legislative and oversight jurisdiction over issues. These benefits come at a cost of exerting effort in bill creation and introduction. A re-election maximizing legislator then weighs these benefits and costs and finds her own optimal bill introduction behavior.

With the behavior of legislators characterized, let us take a policy issue in the position $A$ in Figure 1. This is an issue over which an incumbent committee would normally have 
jurisdiction. We assume a) that the incumbent committee already has a bill under consideration (this is not a necessary condition, but makes exposition easier), and b) that all bills referred to the incumbent committee end up at the ideal policy point of the members (characterized by the median voter of that committee) in the absence of a competing bill.

Now a potential challenger bill arises from a member of another committee. If the challenger does introduce a bill, there is a probability, $p$, that this bill will be referred by the Parliamentarian to the challenger committee, and a probability (1-p) that it will be referred to the incumbent committee. If the bill is referred to the incumbent committee, the bill is assumed to die. To examine the effect of jurisdictional conflicts on policy outcomes, we consider two baseline cases. The first is an open rule, unidimensional median-voter model, where one committee has monopoly agenda-setting power to unilaterally send bills to the floor, but any member on the floor can propose amendments at zero (or very low) costs. In this model, the equilibrium policy is determined by the median floor voter. This is because for any proposal that is not at median voter's ideal point, there is another policy that can be introduced which the median prefers. This makes any proposal that is not on the median voter's ideal point unstable.

Let us consider a second baseline model common in the literature -- a closed-rule, unidimensional median-voter model with monopoly agenda-setting power for the incumbent committee. This is equivalent in theory to the probability of a second bill being referred to the challenger committee being zero $(p=0)$. This is similar to the previous case, except the policy proposed by the incumbent committee cannot be amended. Thus, the median floor voter's decision involves comparing the status quo, $x$, with the bill proposed by the committee, $y$. As long as $y$ is closer to the median voter's ideal point than $x, y$ will be an equilibrium. 
Within this second baseline model, let us examine a serious jurisdictional challenge: a challenger committee receives the second bill with $p=0.3$. All parties know that a member of this challenger committee can credibly threaten to introduce a competing bill, because by introducing that bill, the challenger's committee gains some legislative jurisdiction over the issue and the incumbent committee loses some legislative jurisdiction over the issue (even if the bill does not pass). This, in turn, enhances the bargaining position of the member of the challenger committee. To prevent this loss of jurisdictional claims, the incumbent committee members will move the position of their bill (through mark-up, for example) closer to the challenger's preferences so as to create little incentive for a challenger bill to arise in the first place. This "compromise" solution will be a position such that the member of the challenger committee is no worse off under the bill he or she would have introduced initially plus the expected jurisdictional gains the challenger would make (minus the costs of bill introduction).

What becomes evident is that as $p$ increases, the incumbent committee is willing to introduce a bill closer to the challenger's ideal point. That is, as the threat of a challenger committee member encroaching on the policy space increases, the more the incumbent committee members are willing to attenuate their initial policy position to prevent this encroachment. Thus, members are willing to modify policy for jurisdiction. This is a form of compromise — offering a more moderate policy position to induce no jurisdictional challenge from a potential competitor. This leads to the first hypothesis.

\section{ATTENTUATION HYPOTHESIS}

H1: The greater the probability a challenger bill will be referred to another committee, the more moderate the incumbent committee's policy position will be to prevent jurisdictional encroachment. 
As the theory notes, legislators can engage in trade-offs. There are two prototypical types of models of legislators' utility functions. The first is a spatial model in policy space, where legislators seek to achieve their highest utility policy outcome. The second is a jurisdictional encroachment model, where legislators are trying to obtain the most legislative and oversight jurisdiction feasible. In this paper, legislators will maximize utility over both variables jointly.

We can, moreover, predict those legislators who, within a challenger committee, will have the greatest incentive to act. Jurisdiction has two properties. First, as Hall (1998) notes, committee leadership positions play a leading role in jurisdictional grabs. That is, senior members of the challenging committee (those who are subcommittee chairs and ranking minority members) attempt to expand their current power through these jurisdictional games. In this view, bills that are likely to expand a committee's jurisdiction are sponsored by these highranking members. An alternative view, supported by King (1997), is that legislative jurisdiction takes time to build, over multiple bill referrals in many congresses. Oversight jurisdiction takes time to implement as well (Weingast and Moran 1983). If jurisdiction is a mechanism to produce "revenues" over the long-term, then people who expect to receive that income stream for the longest time should assign the highest value to engaging in jurisdictional grabs. This would suggest that junior members of the challenging committee in safe seats (who can expect to be around for a long time) will have the greatest incentive to engage in jurisdictional challenges. These considerations are not taken into account in the previous theories of bill sponsorship. This leads to Hypothesis 2.

\section{JURISDICTION HYPOTHESES}

$\mathrm{H} 2 \mathrm{a}$ : If legislative and oversight jurisdiction is valued highly enough by members of the challenger committee, the members of the challenger committee will introduce policies that are not close to its ideal point so as to gain jurisdiction.

$\mathrm{H} 2 \mathrm{~b}$ : Senior members in the challenger committee are most likely to sponsor challenger bills. 
H2c: Young members in safe seats on the challenger committee are most likely to sponsor challenger bills.

\subsection{THEORETICAL EXTENSIONS}

One of the recent characteristics of the bill referral process is the use of multiple referral. As Oleszek (2004) describes in detail, there have been at various times over the past 35 years three main mechanisms that a Speaker or Parliamentarian can use to refer a bill to multiple committees: joint referral (referral to multiple committees simultaneously), sequential referral (referral to multiple committees sequentially), and split referral (referral of different parts of the bill to different committees simultaneously). Oleszek argues that the Parliamentarian can minimize hard fought turf wars by exploiting the multiple referral process.

This theory also suggests that multiple referrals might mitigate, but should not negate, the inter-jurisdictional fights. Although the theory is most cleanly applied to the case of a single referral, one of the assumptions of the theory is that even if an incumbent committee is forced to share jurisdiction with a one other or with multiple challenger committees, there is a loss of monopoly power (and the benefits it conveys) to the incumbent committee. The theory predicts that to prevent this, the focal committee will change its proposed policy position, away from its most-preferred policy position, even in a multiple referral situation. Compared to single referrals, multiple referrals may temper turf wars somewhat because the incumbent committee retains some jurisdictional claim, but the theory would also predict that the potential loss of monopoly jurisdiction by the incumbent committee will still cause some policy attenuation.

A second concern articulated that may limit the scope of the theory is an unfavorable policy outcome for the Speaker after moderating the incumbent committee's policy stance. If in averting turf wars between committees, the incumbent committee shifts its position to a policy 
that is further away from the Speaker's ideal point than the non-attenuated position, it would be in the Speaker's interest to bypass the Parliamentarian and refer the bill directly to the incumbent committee. The mere knowledge that a Speaker may do this could affect $p$ and thus mitigate the attenuation hypothesis.

A number of factors should minimize this concern. First, King (1997) suggests that the Speaker has delegated authority consciously in the referral process to the Parliamentarian in order to keep politics and policy out of this aspect. (See footnote 1 for a further explication of this argument.) He cites, as just one example, the fact that Parliamentarians span multiple speakers, have decades of training, and are truly thought of as being unbiased. Second, to the extent Speakers are themselves involved in the bill referral process separate from the Parliamentarian's role, ${ }^{7}$ it is the case that many issues are not so partisan so as to create divisions with the majority party's leadership. However, the theory need not be limited to non-partisan issues. Indeed, third, frequently the Speaker may not have good information with respect to his preferred policy outcome or the degree of moderation that might occur during a committee's deliberations. For example, bills are becoming more complex and their full policy implications less certain because of new problem areas, such as homeland security, advancing technologies, and changing economic situations (Oleszek 2004: 86). Alternatively, as the position of bills reach the fringe position, $A$, it may be difficult for the Speaker to anticipate jurisdictional challenges.

Overall, the theory generates two general predictions. First, legislators will trade off the costs and benefits of obtaining additional jurisdictional scope for the committee with their own policy preferences. Second, legislators will act in predictable ways based on their positions on the committees and their electoral vulnerabilities. In the next section, we examine these 
hypotheses with reference to Internet intellectual property bills.

\section{BACKGROUND: INTERNET DATABASE PROTECTION}

In January 1999, Howard Coble (R-NC) introduced (for a second time), a bill (H.R. 353) to strengthen Internet intellectual property protection (Baron 2000). A group of companies and interest groups, led by eBay, the Realtors Association, and Reed Elsevier, had been pressing Congress to act. The rise of the Internet made it particularly easy for pirates to extract and copy on-line, electronic, and Internet databases. Indeed, many of these companies had become subject to "attack" from "pirates."

For example, Bidder's Edge, a rival to eBay, had built its business model on auction aggregation. The company designed algorithms to search across 120 online auction sites, and then download information from these sites into its own database to be displayed on its own site. The "spiders" copied and downloaded about 80,000 web pages from eBay onto the Bidder's Edge site daily; eBay estimated that Bidder's Edge alone accounted for between 1\% and 1.5\% of the queries received by eBay. This imposed a heavy load on eBay's servers and made its computers operate slower for customers accessing the site directly.

These "attacker" companies sought legal protection under a 1991 U.S Supreme Court decision known popularly as the "Feist" (Feist Publication, Inc. v. Rural Telephone Service Company, 499 US 340). The key question before the Supreme Court involved the scope of copyright protection. What information in databases could be protected? The Feist Court ruled, “....all facts-scientific, historical, biographical and news of the day ... are part of the public domain available to every person." They continued:

"The facts contained in existing works may be freely copied because copyright protects only the elements that owe their origin to the compiler -- the selection, coordination, and arrangement of facts." 
Given that Bidder's Edge was using publicly available facts about auctions, Bidder's Edge argued it stood to reason, in light of the Feist decision, that the facts in the online databases were not protected by copyright, and thus could be copied, provided that their selection, coordination, and arrangement were not.

Against this backdrop, database companies such as Monster.com, NASDAQ, and the NYSE, sought a re-write of the copyright law, and turned to the chair of the House Judiciary Committee, Subcommittee on Courts and Intellectual Property, Howard Coble. eBay, the Realtors, and the publishers prevailed upon Rep. Coble introduced a bill to strengthen the copyright protection afforded to electronic and online databases. In January 1999, Rep. Coble introduced a bill to increase intellectual property protection for electronic databases.

The Collections of Information Antipiracy Act (H.R. 353) introduced by Coble, did not grant copyright protection to facts per se, but it did seek to protect databases and thus overturn Feist. Amending the Sherman Antitrust Act, H.R. 353 made it illegal for any person to: "make available to others, or extract to make available to others, all or a substantial part of a collection of information gathered, organized, or maintained by another person through the investment of substantial monetary or other resources, so as to cause material harm to the primary market or a related market of that other person, ... for a product or service that incorporates that collection of information and is offered or intended to be offered in commerce by that other person...."

Any person who was harmed under the terms of the H.R. 353 could bring a civil court case against the alleged infringer, and ask for the recovery of lost profits, treble damages under the Sherman Act's penalty provisions, and payment of reasonable attorneys' fees. The Act was well received by database producers. As head of the Intellectual Property Subcommittee that had traditionally overseen copyright legislation, Coble was well-positioned to shepherd his bill through the $106^{\text {th }}$ House of Representatives to a final, and expected winning vote on the Republican-majority floor. 
H.R. 353, however, resulted in the organization of a competing coalition of interest groups comprising old and new economy firms and associations that opposed the bill, spearheaded by Yahoo!, NetCoalition (a consortium of ten large Internet companies, including AOL and Amazon), Bloomberg, the U.S. Chamber of Commerce, and the American Research Libraries Association. These database users were concerned about how a strengthening of copyright protection might affect their business models. A large number of universities, including Harvard, Chicago, and Stanford, (and their associated research libraries) argued if database companies were able to compile and copyright the facts from their databases, scientific research of all types would be constrained significantly and might even be slowed to a snail's pace. Smaller universities, too, articulated concerns that if H.R. 353 became law it would hamstring their teaching missions because materials and databases used for teaching purposes would no longer be accessible.

In May 1999, as H.R. 353 was working its way through the Judiciary Committee, this coalition persuaded Thomas Bliley (R-VA), chairman of the Commerce Committee, to introduce a competing bill that had the effect of codifying into proposed legislation the Feist decision with some small additional protections. This bill, the Consumer and Investor Access to Information Act of 1999 (H.R. 1858), was referred to the Commerce Committee, Subcommittee on Telecommunications, Trade, and Consumer Protection. H.R. 1858 made it:

“... unlawful for any person or entity...to sell or distribute to the public a database that--

(1) is a duplicate of another database that was collected and organized by another person or entity; and

(2) is sold or distributed in commerce in competition with that other database"

Enforcement of the Act rested with the Federal Trade Commission (FTC), and violators of the Act were punished under the rules respecting unfair or deceptive acts or practices under section 5 of the enabling legislation, a much more lenient punishment than H. R. 353 prescribed. 
Under Rule X, the House Commerce Committee is granted jurisdiction over the Federal Trade Commission. There were now two competing bills in Congress in two committees.

In Figure 2, we outline in a one-dimensional spatial diagram, the positions of the players. Feist $(F)$ was a lenient outcome, offering very low protection to databases. The Judiciary Committee introduced a bill with very strong protections, which it manifested in the introduction of the H.R. $353(C)$. We place $C$ opposite $F$, but closer to the median voter, $M$, than to $F$, the median voter. Thus, an unopposed Coble bill would likely become law because it captures the median voter. Finally, the Commerce Committee introduced H.R. $1858(B)$, such that it was on the interval $[F, C]$. We place it to the right of Feist, and closer to the median voter than $C$.

\section{EMPIRICAL ANALYSIS}

In this section, we examine empirically the predictions of the committee jurisdiction model on legislator behavior, committee behavior, and policy outcomes. We explore the two theoretical hypotheses by examining the copyright dispute between the two committees. While none of the evidence presented provides unequivocal proof of the theory, the goal of this section is to provide multiple pieces of evidence that together will build a sufficiently convincing story that the theoretical mechanisms discussed in Part III actually are operating.

\subsection{ATTENTUATION HYPOTHESIS}

In examining the evidence for Hypothesis 1, we establish two main facts: the Judiciary Committee was the incumbent committee, and the probability of a challenger committee arising was so small that the Judiciary Committee did not attenuate its extreme position. If the probability had been high, then, in equilibrium, the Judiciary Committee should have introduced a moderate bill, close to the preferences of the competing committee, to stave off a jurisdictional 
challenge. If the probability was low that a challenger committee would become involved, then the bill introduced by the Judiciary Committee could more closely reflect the preferences of the committee, and thus be more extreme.

There are three main factors suggesting that the Judiciary Committee was the incumbent committee, and that it was likely to receive H.R. 353. First, Representative Coble had a longstanding interest in the bill. This was not the first time a nearly identical version of this same bill had gone through the House. The earlier bill was also referred to the Judiciary Committee in the $105^{\text {th }}$ Congress, giving precedent for the more recent bill to follow the same committee referral path. Second, Coble's staff, with the help of like-minded interest groups, had written H.R. 353. King (1997) notes that bills contained language so as to route the bill to certain committees. For example, H.R. 353 extended the Sherman Act, a law that was under Rule X's jurisdiction of the Judiciary Committee. Finally, the Judiciary Committee had a long-established precedent for handling bills covering copyright. Table 1 examines all legislative hearings covering proposed copyright bills in the $80^{\text {th }}$ through $103^{\text {rd }}$ congresses (1946-1994). The data include every congressional hearing reported by the Congressional Information Research Service over that period. Each hearing is categorized further into 222 topics (of which copyright is one); we further limit our analysis to legislative hearings. ${ }^{8}$ During this nearly 50 -year period, the Judiciary Committee received $86 \%$ (127) of copyright referrals. (We compare this to very stable issues areas, such as agriculture, which exhibits an $86 \%$ to $90 \%$ probability of bill referral to the Agriculture Committee.) We assume that this was the lowest probability that the Coble bill would have been referred to the Judiciary committee.

The second fact we try to establish is the degree of and reasons for attenuation. If the somewhat extreme position of H.R. 353 is to be an equilibrium policy choice for the Judiciary 
Committee, then we must assess the probability $(p)$ that a challenger bill would be referred to a second committee for consideration. If $p$ is high, then Coble should have introduced a bill that was moderate; if $p$ is low the bill can mirror the Judiciary Committee's preferences in equilibrium. ${ }^{9}$ As noted in Table $1,14 \%$ of legislative hearings on copyright bills were sent to another committee. Thus, there was an unconditional probability of $14 \%$ that another committee might get a second bill. The Science, Space and Technology Committee (under various names) received the second most number of copyright bill referrals at 5\% (8) during 1946-1994, and posed perhaps the greatest threat for producing a competing bill. However, Representative James Sensenbrenner (R-Wis), Chairman of the Science, Space, and Technology Committee, was in line to ascend to the chair of the Judiciary Committee, and did not want to undermine the possibility of this coming to fruition in the next congress. He was thus reticent to introduce a bill competing with the Judiciary Committee's bill. With the Science Committee unlikely to introduce a bill, the base probability that Coble faced was about $p=9 \%$ that another committee would introduce and receive a competing bill. ${ }^{10}$ Thus, the behavior of the Judiciary Committee in introducing a somewhat extreme proposal is reasonable and therefore consistent with the Attenuation Hypotheses.

A final fact we attempt to establish is that the Representative Coble's staff did not expect a jurisdictional challenge to H.R. 353, and therefore introduced a bill that reflected the preferences of the committee without attenuation. As part of this study, we conducted interviews with 15 lobbyists who represented various interest groups on both sides of H.R. 353 and H.R.

1858. One lobbyist who helped to write and spearhead H.R. 353 noted:

\footnotetext{
"We were a bit surprised by the extent of opposition to H.R. 353. Representative Coble has strong views on the need to protect databases and he understood our position. He had introduced a very similar bill in the last Congress. When we worked with Representative Coble's staff, we discussed the possibility of another bill being introduced - possibly by another committee — and we dismissed that idea.... Would we have recommended a bill with lower penalties if we had
} 
known the opposition were [sic] going to introduce H.R. 1858? Possibly —it would have been a bill with fewer penalties and possibly more exemptions - but it is hard to know because we ... never really discussed it."

Later he said:

"We wrote [H.R. 353] to amend the [Sherman Antitrust Act] so that we [the Judiciary Committee] would get the bill. They [the H.R. 1858 coalition] were pretty clever to use the FTC [Federal Trade Commission] [in H.R. 1858] to try to sap support for our bill."

Another lobbyist, representing an interest group that opposed H.R. 353, said,

"We tried to negotiate with them [H.R. 353 supporters], but they wouldn't budge. We explained how this could potentially destroy our businesses - really hurt the development of the Internet. They still wouldn't budge. I think they were surprised when found a way to introduce H.R. 1858 [around the Judiciary Committee and] into the Commerce Committee."

The views of the lobbyists interviewed on both sides of the issue during the jurisdictional fight (to extent that they are reflective of congressional opinion) provide additional evidence that jurisdiction and policy attenuation issues were contemplated by legislative staffs. Moreover, we find additional evidence for this hypothesis in the next section's statistical analysis.

\subsection{JURISDICTION HYPOTHESES}

Hypothesis 2a predicts that challenger committee members may not support bills in their best policy interest if they believe that such a position will expand the scope of the committee's legislative and oversight jurisdictional responsibilities. While the theory in Section 2 does not exclude the possibility that bills will be introduced by challengers with policy positions they support, there are few theories that predict that bills that are not in the policy interests of legislators will be introduced.

To test this hypothesis, we examine bill co-sponsorship and its relationship to turf wars using multivariate statistical analysis focusing on the policy-jurisdiction trade-off. As noted in Section 3, oversight of the implementation of database copyright bills was to be delegated to the 
courts in H.R. 353 and to the FTC in H.R. 1858. Hence, Coble and Bliley delegated implementation of their respective bills to surrogates for which they had proximate control.

If Hypothesis 2a is credible, we should see the sponsors of H.R. 353 supporting their constituents' preferences. H.R. 353's sponsors believe ex ante that the likelihood for a challenge to the Coble-sponsored bill was low; thus, to them, the jurisdictional benefits were moot. Supporters of H.R. 1858 could be responsive to their constituents, or to jurisdictional issues. If we find the constituency responsiveness, this is consistent with a host of different theories. However, if we do not find evidence of constituency responsiveness, but do find jurisdictional responsiveness, the results will be consistent with a theory of jurisdictional conflict.

We begin by considering as our dependent variable whether a legislator co-sponsored H.R. 353 (1) or not (0). In a second set of specifications, we consider whether a legislator cosponsored H.R. 1858 (1) or not (0). We consider four types of independent variables. The first variable, EDUCATIONAL EMPLOYMENT (from the Bureau of the Census), measures the amount of educational employment (in thousands) in a legislator's district. Given that within congressional districts, the number of school-age children does not differ greatly, any differences in educational employment across districts is usually due to the presence of one or more universities in the district. Recall that only universities were a cleanly identifiable industry sector that was uniformly opposed to H.R. 353, and supported H.R. 1858. Over 100 individual universities and nearly all university trade groups representing community colleges through Carnegie I research universities, publicly expressed opposition to H.R. 353 and support for H.R. 1858. Thus educational employment should be correlated with constituent preferences. ${ }^{11}$

The second set of variables identifies the committee assignments of the legislators, to control for jurisdictional disputes. Dummy variables for membership on the House 
COMMERCE COMMITTEE, JUDICIARY COMMITTEE, and SCIENCE COMMITTEE are coded from the Congressional Quarterly. The third set of variables measures the ADA score of the representative (provided by Professor Timothy Groseclose), as a proxy for the legislator's ideology. Finally, a number of control variables for the representative's district are coded to control for constituent characteristics that might be related to outcomes of the bills. These include MEDIAN INCOME (in thousands of dollars), MEDIAN HOME VALUE (in hundreds of thousands of dollars) (as a measure of wealth), and the number of individuals (in thousands) with college degrees (EDUCATIONAL ATTAINMENT). All of these latter variables are derived from the STF3 file of the 1990 U.S. Census of Housing and Population. ${ }^{12}$

The predictions of the theory with respect to Hypothesis $2 \mathrm{a}$ are threefold. First, to the extent that the incumbent committee members believe they are acting in a setting where committee jurisdictions are unchallenged, the proposed bill proposed should reflect the true policy concerns of its sponsors' constituents. Therefore, we should find the coefficients on educational employment to be negative and statistically significant for the H.R. 353 regressions. Second, if the members of the challenging (Commerce) committee are seeking jurisdiction, and not actual policy outcomes, they should not be voting in ways consistent with their constituents' preferences. So the coefficients on educational employment for H.R. 1858 should not be statistically significant. Finally, jurisdictional conflict between committees should be manifested in committee memberships, with committee members splitting their votes to support their own bills. Thus, in the H.R. 353 regression, there should be a positive coefficient on the Judiciary Committee variable and a negative coefficient on the Commerce Committee variable. The opposite should be true of the H.R. 1858 regressions. All three of these predictions together are 
consistent with the various predictions of Hypothesis 2a, and the latter two are inconsistent with theories of committee monopoly power.

I have estimated this model with a probit, logit, and rare events probit (King and Zeng 2001) specifications, and all have nearly identical results. We present the results of a probit analysis in Table 2. In all statistical models in this paper, the coefficients report the change in the probability of the dependent variable for an infinitesimal change in each independent, continuous variable and, by default, the discrete change in the probability for dummy variables. The two-sided t-statistics are presented below the coefficient estimates, with the 95\%, and 99\% significance level noted for each coefficient. Models (1) and (2) use H.R. 353 as the dependent variable; Models (3) and (4) use H.R. 1858 as the dependent variable. Models (1) and (3) contain only the constituency and ideology variables; Models (2) and (4) include the committee assignment variables. H.R. 353 was cosponsored by $17 \%$ of the members of Congress; the sponsors of H.R. 1858 represented only about 4\% of the House's membership.

In Models (1) and (2) the coefficient on educational sector employment is negative and statistically significant as predicted. In no specification is the coefficient on ADA score or any other control variables statistically significant. Replacing ADA score with the party affiliation of the representative has no qualitative effect on the results. The large negative coefficient on educational employment for Models (1) and (2) is consistent with H.R. 353's co-sponsors voting with the preferences of the constituents. Every 10,000-person (about 1.5\%) increase in educational employment (roughly the employment of a large university in the district) makes a legislator 7.7\% less likely to sponsor H.R. 353. This is consistent with the first prediction and also provides further support for the Attenuation Hypothesis. In Models (3) and (4), the coefficients on educational employment are not statistically different from zero. This is 
consistent with H.R. 1858 supporters not sincerely voting with their constituents' interests, which supports the second prediction.

Finally, the four coefficients on the Judiciary and Commerce Committee membership variables are all large in magnitude, signed as predicted, and three of the four are statistically significant. Science Committee members exhibit no discernible higher or lower co-sponsorship tendencies for the two bills than other members of the House. A Commerce Committee member is $10.1 \%$ less likely to cosponsor H.R. 353 than the average House member, and $23.4 \%$ more likely to cosponsor H.R. 1858 than the average member. A Judiciary Committee member is $33.5 \%$ more likely to cosponsor H.R. 353 and $1.1 \%$ less likely to the cosponsor H.R. 1858 than the average House member. This last coefficient on Judiciary Committee membership is negative as expected, but does not reach statistical significance. Rep. Rick Boucher, who sits on both the Commerce and Judiciary Committees, was the only Judiciary Committee member to cosponsor the Bliley bill. The small number of sponsors (18) likely drives the lack of statistical significance on this coefficient. Other than this consideration, all coefficients come out as expected. This last result on committee membership is consistent with the third prediction of jurisdictional battles between committees.

Together, these three results suggest that turf wars are important, and that the incumbents, not expecting a challenge, acted more sincerely than the challengers did in the policy domain, consistent with Part 2a of the Jurisdictional Hypothesis.

Hypotheses $2 \mathrm{~b}$ and $2 \mathrm{c}$ further refine the predictions about bill introduction. They predict that senior members overall and junior members in safe seats of the challenging committee will have the greatest incentive to exert effort in mounting a jurisdictional challenge. The legislators 
who gain the most from jurisdictional disputes are those who can take advantage of the committee's current jurisdiction, and those who value the property right over the long term.

To test this hypothesis, we conduct an econometric analysis of the co-sponsorship behavior of members of the challenging committee. We consider the identities of the members of the Commerce Committee $(n=53)$ who co-sponsored H.R. 1858, the challenging bill, using as our dependent variable whether a member of the Commerce Committee cosponsored H.R. 1858 (1) or not (0). The independent variables are as before, but this time we include three additional variables. The first is COMMITTEE RANK. This is an ordinal measure of Commerce Committee seniority (obtained from the Congressional Quarterly) and ranges from 1 (for the chairman or ranking member) to 29 (for the most junior members). The second is ELECTION MARGIN. It is a measure of how safe the member is in her seat (margin of victory in thousands of votes in the last election) (obtained from the Clerk of the House). Finally we interact COMMITTEE RANK with ELECTION MARGIN. We predict that the coefficient on COMMITTEE RANK should be negative (more senior members are more likely to support challenging bills) and the coefficient on the interaction variable of ELECTION MARGIN*COMMITTEE RANK should be positive (junior members with larger margins of victory in the last election are more likely to support challenging bills).

The results of the probit analysis are presented in Model (5) of Table 3. Congruent with our earlier findings, legislator ideology, educational employment, and the control variables do not have statistically significant coefficients. ${ }^{13}$ There is, however, a statistically significant relationship between the two variables of theoretical interest and the dependent variable. Senior members of the Commerce Committee are more likely to sponsor H.R. 1858. Each step up on the committee makes an individual 4.4\% more likely to sponsor H.R. 1858. Moreover, junior 
legislators with large vote margins in the last election are more likely to support H.R. 1858 than are others. These results provide evidence that is consistent with the hypothesis of Hall (1998) (Hypothesis 2b) and King (1997) (Hypothesis 2c). ${ }^{14}$

These results can also be juxtaposed with those of Krehbiel's (1995) examination of budget bills, which shows that electoral margins make no difference in bill co-sponsorship, while more junior members of committees are more likely to co-sponsor bills. One key factor that differentiates Krehbiel's work from this study is that there is no jurisdictional conflict in Krehbiel's analysis of budget votes. Indeed, it may be that precisely because there is jurisdictional conflict, the current paper refines the results of Krehbiel. Junior members get little benefit from jurisdiction (in this paper), but may derive considerable benefit from high profile co-sponsorship on budgeting issues (in Krehbiel's paper). However, representing safe districts makes enormous difference to junior members in jurisdictional disputes, and can lead to more co-sponsorship.

\subsection{LIMITATIONS}

The current empirical work is not without limitations. First, the setting provides only a weak test of the attenuation hypothesis. This hypothesis predicts that legislators will attenuate policy outcomes close to their preferences to deter jurisdictional challenges. In fact, the empirical evidence on the Judiciary Committee argues the inverse: the Judiciary Committee did not expect a jurisdictional challenge so it did not attenuate policy. Although this evidence is consistent with the attenuation hypothesis, a more robust test would allow the researcher to more concretely examine the attenuation hypothesis. ${ }^{15}$

Second, the results in Models 1-4 must be interpreted a bit carefully. Although a chisquare test of the coefficients on Educational Employment and Commerce Committee in Model 
4 rejects that they are jointly equal to zero, the test for attenuation is again a weak one. Models 3 and 4 reject that legislators are more likely to sponsor H.R. 1858 if Educational Employment in the district is large. This fact is consistent with the theory, but this is the null, and therefore a less than ideal test. ${ }^{16}$ For example, we cannot reject the conjecture that extreme policy results from interest group action. A better test is certainly called for in future work.

Third, because the discussion here is a case study, its generalizability may be limited. Moreover, because the incumbent committee did not engage in attenuation (but, thought about it, according to the lobbyists), the paper maintains a somewhat weak test of the attenuation hypothesis. We also recognize that while much of the evidence is consistent with the hypothesis it is not conclusive. Rather, the paper has attempted to bring together multiple pieces of evidence to demonstrate that the attenuation hypothesis was in play. We believe that the preponderance of the evidence regarding motivations and outcomes suggests that attenuation occurs. That said, a large sample study would seem to be warranted for future research.

\section{CONCLUSION}

Jurisdictional conflict between committees within Congress is common and increasing (Baumgartner et al. 2000). The theoretical perspective developed in this paper extends a small but important body of literature examining congressional committee jurisdiction. It demonstrates that actors with foresight can have large impacts on policy outcomes by merely threatening to engage in jurisdictional turf wars. Moreover, legislators and committees will engage in jurisdictional turf wars even if that means introducing sub-optimal legislation from the sponsor's viewpoint. This is because the gains from obtaining a slice of legislative or oversight jurisdiction over an issue may result in a greater gain to utility than the loss of a particular policy position. In 
many cases, policy outcomes are predicted to be closer to the status quo than they would be in the unidimensional, closed rule, monopoly committee dominance literature.

The paper examines two Internet intellectual property protection bills before the $106^{\text {th }}$ Congress, to test implications of the theory. The descriptive and statistical evidence illustrates how jurisdictional wars between committees play out. The evidence is consistent with the main tenets of the paper. This paper sheds new light on the committee jurisdiction literature. It suggests that scholars examining the relationship between committee behavior and policy outcomes should be careful to consider the jurisdictional disputes that could potentially arise and how that might affect policy outcomes. Without controlling for this effect, scholars may generate spurious results. This analysis will help guide thinking about how these effects play out.

Acknowledgement: I would like to thank David King, Romain Wacziarg, and seminar participants at Stanford, MIT and the Berkeley Franco-American Conference on the History, Economics and Law of Intellectual Property Protection for helpful comments. Daniel Braga and Karen Freeman provided excellent for research assistance.

\section{REFERENCES}

Adler, E. Scott, and Dennis Still. "Redefining Committee Jurisdictions: A Bill Referral Approach.” Presented at the Midwest Political Science Association annual meeting, Chicago, IL, April, 2000.

Balla, Steven (2000). "'Legislative Organization and Congressional Review of Agency Regulations," Journal of Law, Economics, and Organization 16(2): 424-448.

Baron, David P. (2000). “eBay and Database Protection,” Stanford Business School, Case S-P-33. 
Baumgartner, Frank R., and Bryan D. Jones (1993). Agendas and Instability in American Politics. Chicago: University of Chicago Press.

Baumgartner, Frank B., Bryan D. Jones, and Michael C. MacLeod (2000). “The Evolution of Legislative Jurisdictions," Journal of Politics 62: 321-349.

Bimber, Bruce (1996). The Politics of Expertise in Congress. Albany, NY: State University Press of New York.

de Figueiredo, John M. (2002). “Committee Jurisdiction and Internet Intellectual Property Protection," MIT Working Paper.

de Figueiredo, John M., and Brian S. Silverman (2006). “Academic Earmarks and the Returns to Lobbying," Journal of Law and Economics 49(2): 597-625.

Feist Publications, Inc. v. Rural Telephone Service Company, 1991; 499 US 340.

Gilligan, Thomas, and Keith Krehbiel (1989) “Asymmetric Information and Legislative Rules with Heterogeneous Committees," American Journal of Political Science 33(2): 459-490.

Hall, Richard L., and Frank W. Wayman (1990). "Buying Time: Moneyed Interests and the Mobilizations of Bias in Congressional Committees.” American Political Science Review 3: 797-820.

Hall, Richard L. (1998). Participation in Congress. New Haven: Yale University Press.

Hardin, John W. (1998). “Advocacy versus Certainty: The Dynamics of Committee Jurisdiction Concentration," Journal of Politics 60(2): 374-397.

Jones, Bryan D, Frank R. Baumgartner, and Jeffery C. Talbert (1993). “The Destruction of Issue Monopolies in Congress," American Political Science Review 87: 657-71.

King, David C. (1994). "The Nature of Congressional Committee Jurisdictions," The American Political Science Review 88(1): 48-62. 
King, David C. (1997). Turf Wars: How Congressional Committees Claim Jurisdiction. Chicago: University of Chicago Press.

King, Gary, and Langche Cheng (2001). "Logistics Regression in Rare Events Data," Political Analysis: 137-154.

Krehbiel, Keith (1992). Information and Legislative Organization. Ann Arbor, MI: University of Michigan Press.

Krehbiel, Keith (1995). “Cosponsors and Wafflers from A to Z," American Journal of Political Science 39(4): 906-923.

Kroszner, Randall S., and Thomas Strattman (2000). "Congressional Committees as Reputation-Building Mechanisms: Repeat PAC Giving and Seniority on the House Banking Committee," Business and Politics 2: 35-52.

Kurtz, Glen S. (2001). "Tactical Maneuvering on Omnibus Bills in Congress,” American Journal of Political Science 45(1): 210-223.

Mayhew, David R. (1974). Congress: The Electoral Connection. New Haven: Yale University Press.

McCubbins, Mathew D., and Thomas Schwartz (1984). “Congressional Oversight Overlooked: Police Patrols versus Fire Alarms," American Journal of Political Science, 28(1): 165-179. McNollgast (1987). “Administrative Procedures as Instruments of Political Control,” Journal of Law, Economics and Organization 3:243-277.

Oleszek, Walter J. (2001). “The Internet and Congressional Decisionmaking,” A Report Prepared for the Chairman of the House Rules Committee, September 19: Congressional Research Service. 
Oleszek, Walter J. (2004). Congressional Procedures and the Policy Process. CQ Press: Washington, D.C.

Schiller, Wendy J. (1995). "Senators as Political Entrepreneurs: Using Bill Sponsorship to Shape Legislative Agendas," American Journal of Political Science 39(1): 186-203.

Snyder, James (1991). “On Buying Legislatures,” Economics and Politics 3(2): 93-109.

Snyder, James (1992). "Long-Term Investing in Politicians; Or, Give Early, Give Often" Journal of Law \& Economics 35: 15-43.

Talbert, Jeffery, Bryan Jones, and Frank Baumgartner (1995). "Non-Legislative Hearings and Policy Change in Congress," American Journal of Political Science 39: 383-406.

Weingast, Barry R., and William Marshall (1988). "The Industrial Organization of Congress; or, Why Legislature, like Firms, Are Not Organized as Markets," Journal of Political Economy 96: 132-96.

Weingast, B., and P. Moran (1983). “Bureaucratic Discretion or Congressional Control? Regulatory Policymaking by the Federal Trade Commission," Journal of Political Economy 91: 765-800. 


\section{ENDNOTES}

${ }^{1}$ As King (1997: 79-80) notes: "the House parliamentarians are described as neutral arbiters of jurisdictional disputes. Although these guardians are agents of the Speaker, who is an agent of the majority party, the Speaker abides by advice from the parliamentarians when turf wars arise. ... Today, although the House rules say that the Speaker refers bills, the Speaker's referrals are overwhelmingly guided (and usually written) by the parliamentarian. Following the revolt against Cannon in 1910 (and the brief "King Caucus" period of the early 1910s), jurisdictional arbitration was largely taken out of partisan hands and given to the parliamentarian, who uses nonpartisan decision rules that reward jurisdictionally proximate committees.” For a further discussion of this important assumption, see King (1997: 78-88) and Section IIC of this paper.

${ }^{2}$ A formal model can be found at http://www.law.duke.edu/fac/defigueiredo

3 "Why fight over committee jurisdictions? These battles are about power, influence and property rights over public policies. From the Latin words juris and dictio, jurisdiction literally means the right or authority to make pronouncements that are binding and are backed up by law. 'No characteristic of the committee system,' writes the Congressional Research Service, 'is more critical than its jurisdictional structure — the way in which it divides and distributes control over policy subjects."” (King 1997: 11-12). In addition Oleszek (2004: 81) also quotes individual legislators identifying jurisdiction's importance. ${ }^{4}$ This assumption is necessary for the scope of strategic bill introduction by legislators.

${ }^{5}$ For example, antitrust enforcement of entertainment firms is left to the Department of Justice, though both Commerce and Judiciary Committees have legislative jurisdiction for antitrust.

${ }^{6}$ If bill introduction is a cost-free exercise, then the expected net benefit to introducing a bill is strictly positive for all members of Congress for any $p>0$. However, the cost is not zero. Members with experience, expertise, and interest in the focal policy issue or related policy issues will likely have lower costs of formulating policy in the focal area at hand. That is, it is very expensive for an Agriculture 
Committee member to write a bill regarding copyright, but it is less expensive for a Commerce Committee member.

${ }^{7}$ This may be true recently as the Republicans fired two Senate Parliamentarians in early 2000s as they referred key bills in a manner inconsistent with the Majority Leader's wishes.

${ }^{8}$ The data were obtained from the Center for American Politics and Public Policy web page at the University of Washington, http://depts.washington.edu/ampol/.

${ }^{9}$ H.R. 353 likely reflected the sincere preferences of the Judiciary Committee. To establish sincerity of the preferences, we turn to two main arguments. First, the current bill was almost identical to the bill introduced into the previous Congress, when there was no jurisdictional challenge. Second, H.R. 353 reflected the consistent behavior and rhetoric of the Judiciary Committee in supporting strong protections for intellectual property rights. Although the Coble bill had the support of the median voter ( as indicated by the voice vote in the previous Congress) it was stronger than the Feist decision.

${ }^{10}$ King has pointed out that in reality, the true probabilities are probably much lower than reflected in this paper, but highly correlated with the estimated probabilities.

${ }^{11}$ We attempted to identify another measure of university presence. Following de Figueiredo and Silverman (2006), we downloaded from the Department of Education, Division of Education Statistics, the names and zip codes of every post-secondary institution in the United States in 1999 from the Integrated Postsecondary Education Data System. We then examined all Carnegie-designated institutions. There are 434 districts with Carnegie designated institutions which makes it infeasible to use the presence of a university in a district as an alternative measure to Educational Employment.

${ }^{12}$ The maximum correlation between any of these three control variables is 0.76 . The results presented herein are robust to dropping any one of these control variables.

${ }^{13}$ The lack of statistical significance on the Educational Employment coefficient is subject to the caveats in Section IV,C. 
${ }^{14}$ A similar analysis done on Judiciary Committee H.R. 353 cosponsors finds that neither of these variables have a statistically significant effect. This is consistent with the theory, because only challenger committees stand to gain jurisdiction from these jurisdictional turf wars.

${ }^{15}$ The statistical test of H.R. 1858 attempts to address this issue.

${ }^{16}$ A second possible reason for this result is that there is more variance in Educational Employment for non-Bliley supporters than for Bliley supporters. Although, the standard deviation is $25 \%$ higher, it is still less than $5 \%$ of the mean value of the variable, which is likely not quite large enough to singlehandedly drive the t-statistic on the Educational Employment coefficient down to such a low level in Model 4. 


\section{Figure 1: Scope of Jurisdiction}

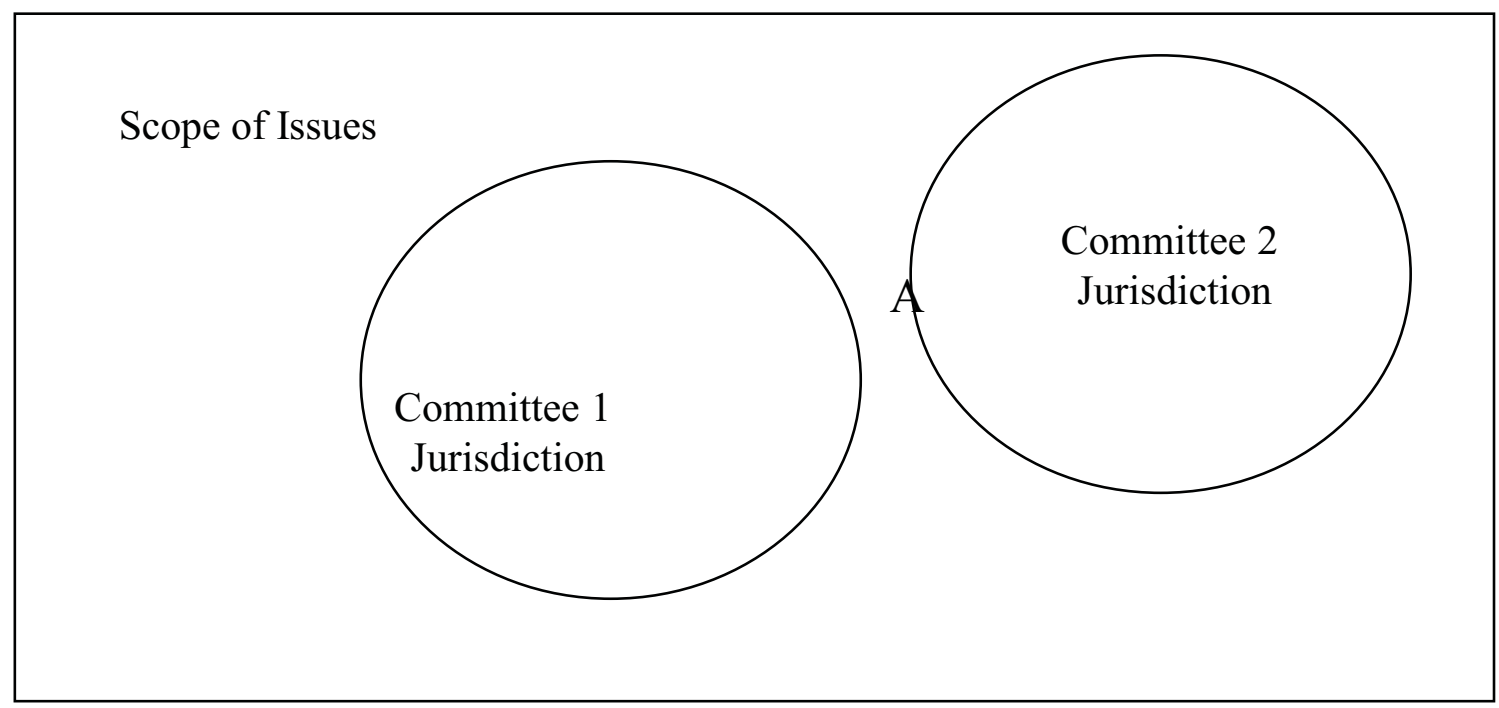


Figure 2: Preference Ordering

\author{
IP Protection (IPP)
}

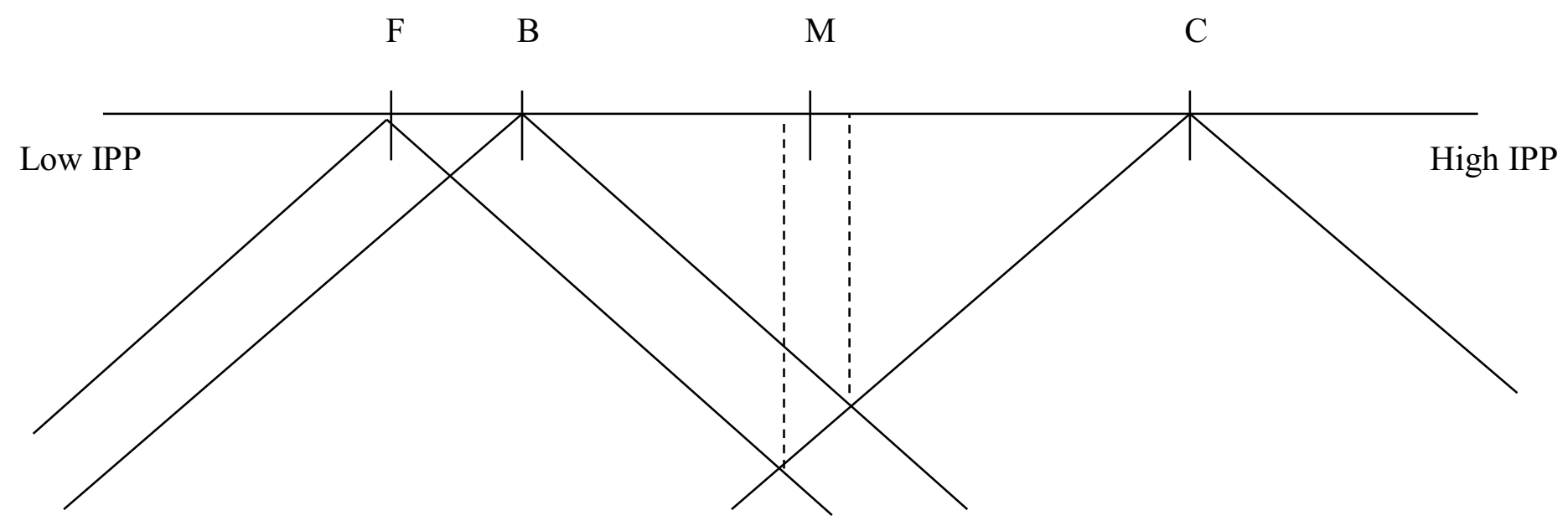




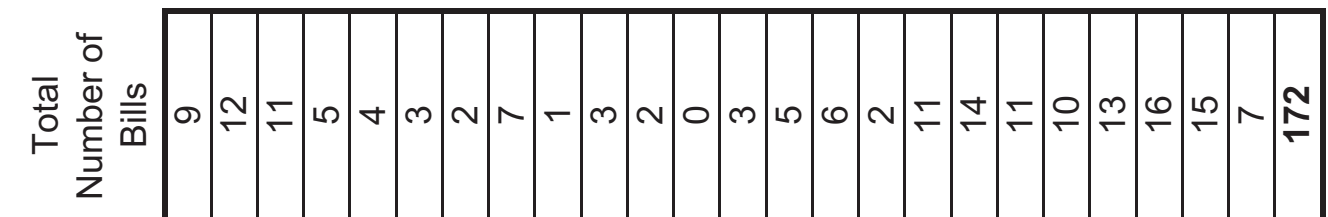

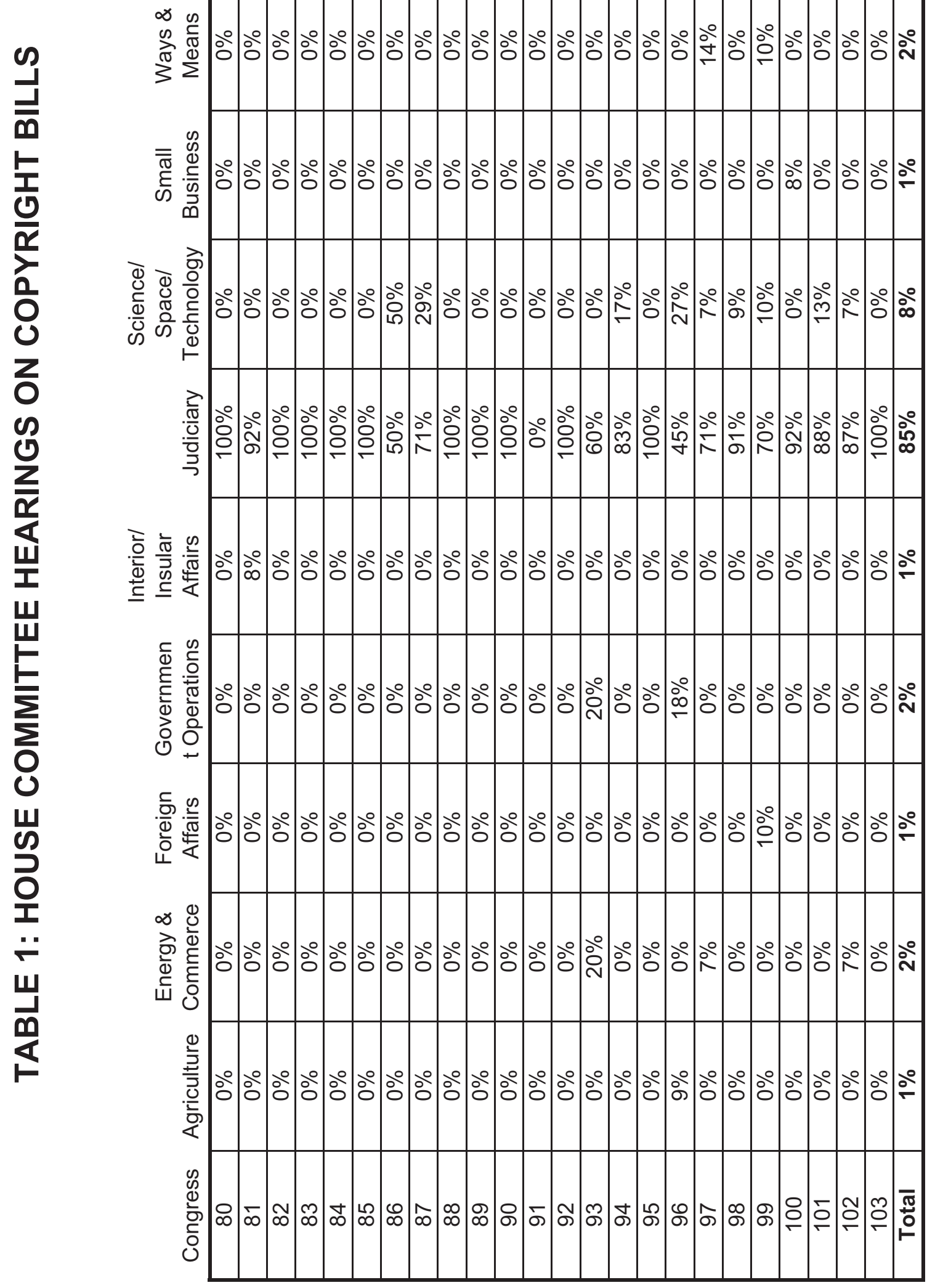


TABLE 2: ECONOMETRIC RESULTS FROM BILL COSPONSORSHIP

\begin{tabular}{|c|c|c|c|c|}
\hline$\underline{\text { Variable }}$ & $\frac{\text { H.R. } 353}{\text { Model } 1}$ & $\frac{\text { H.R. } 353}{\text { Model } 2}$ & $\frac{\text { H.R. } 1858}{\underline{\text { Model } 3}}$ & $\begin{array}{l}\text { H.R. } 1858 \\
\text { Model } 4 \\
\end{array}$ \\
\hline Educational Employment & $\begin{array}{c}-0.0083^{* *} \\
(-2.11) \\
\end{array}$ & $\begin{array}{c}-0.0078^{* *} \\
(-1.99) \\
\end{array}$ & $\begin{array}{c}0.0004 \\
(0.19) \\
\end{array}$ & $\begin{array}{c}0.0008 \\
(0.54) \\
\end{array}$ \\
\hline Commerce Committee & & $\begin{array}{c}-0.1014^{* *} \\
(-1.96) \\
\end{array}$ & & $\begin{array}{c}0.2344^{* * *} \\
(5.88) \\
\end{array}$ \\
\hline Science Committee & & $\begin{array}{c}-0.0278 \\
(-0.50)\end{array}$ & & $\begin{array}{c}0.0179 \\
(0.71)\end{array}$ \\
\hline Judiciary Committee & & $\begin{array}{c}0.3350^{* * *} \\
(4.55)\end{array}$ & & $\begin{array}{c}-0.0112 \\
(-0.49) \\
\end{array}$ \\
\hline ADA & $\begin{array}{c}-0.0003 \\
(-0.58) \\
\end{array}$ & $\begin{array}{c}-0.0002 \\
(-.44) \\
\end{array}$ & $\begin{array}{c}-0.00015 \\
(-0.56) \\
\end{array}$ & $\begin{array}{c}-0.00003 \\
(-0.21) \\
\end{array}$ \\
\hline Median Home Value & $\begin{array}{c}0.0026 \\
(0.07) \\
\end{array}$ & $\begin{array}{c}-0.0073 \\
(-0.18) \\
\end{array}$ & $\begin{array}{c}0.0104 \\
(0.48) \\
\end{array}$ & $\begin{array}{c}0.0018 \\
(0.09) \\
\end{array}$ \\
\hline Median Income & $\begin{array}{c}0.0003 \\
(0.78) \\
\end{array}$ & $\begin{array}{c}0.0036 \\
(0.94) \\
\end{array}$ & $\begin{array}{c}-0.0016 \\
(-0.72) \\
\end{array}$ & $\begin{array}{c}-0.0012 \\
(-0.85) \\
\end{array}$ \\
\hline Educational Attainment & $\begin{array}{l}.0016 \\
(1.08) \\
\end{array}$ & $\begin{array}{l}0.0017 \\
(1.17) \\
\end{array}$ & $\begin{array}{c}-0.0001 \\
(-0.17) \\
\end{array}$ & $\begin{array}{c}-0.0002 \\
(-0.29) \\
\end{array}$ \\
\hline $\begin{array}{l}\mathrm{n} \\
\mathrm{LL}\end{array}$ & $\begin{array}{c}435 \\
11.50\end{array}$ & $\begin{array}{r}435 \\
37.39 \\
\end{array}$ & $\begin{array}{l}435 \\
1.45\end{array}$ & $\begin{array}{c}435 \\
38.70\end{array}$ \\
\hline
\end{tabular}

Two-sided t-statistics below coefficient estimates

** $95 \%$ significance

*** $99 \%$ significance 
TABLE 3: COMMERCE COMMITTEE MEMBERSHIP COSPONSORS

\begin{tabular}{|c|c|}
\hline$\underline{\text { Variable }}$ & $\underline{\text { H.R. 1858 }}$ \\
\hline \hline Educational Employment & $\begin{array}{c}-0.0026 \\
(-0.26)\end{array}$ \\
\hline ADA & $\begin{array}{c}-0.0003 \\
(-0.01)\end{array}$ \\
\hline Median Home Value & $\begin{array}{c}-0.0109 \\
(-0.02)\end{array}$ \\
\hline Median Income & $\begin{array}{c}-0.0031 \\
(-0.50)\end{array}$ \\
\hline Educational Attainment & $\begin{array}{c}0.0006 \\
(0.22)\end{array}$ \\
\hline Committee Rank & $-0.0441^{* *}$ \\
\hline Election Margin & $\begin{array}{c}-0.0019 \\
(-0.89)\end{array}$ \\
\hline Lommittee Rank ${ }^{*}$ Election & $\begin{array}{c}0.0004^{* *} \\
(2.06)\end{array}$ \\
\hline Margin & $\begin{array}{c}53 \\
-18.76\end{array}$ \\
\hline \hline
\end{tabular}

Two-sided t-statistics below coefficient estimates

** $95 \%$ significance 
Committee Jurisdiction, Congressional Behavior and Policy Outcomes

\section{APPENDIX: A SHORT FORMAL MODEL}

We begin characterizing the general game, and then apply it to the expected equilibrium behavior of the H.R. 353 and 1858.

There are two committees $(J$ and $T)$, and there are three legislators $(P, Q$, and $R)$. We note $J$ as the "incumbent" committee, and $T$ as the "challenging committee." $P$ is a member of $J$ and fully embodies the preferences and policies of the $J . P$ can be thought of as the median voter of $J$, or as the committee chair. For simplicity, as we explicate the game, we drop the subscript of $P$ and refer only to $J$ or to the "incumbent" or "incumbent committee." $Q$ and $R$ are members of committee $T$.

The moves of the game are as follows. First, the incumbent chooses a policy $C$, and simultaneously, the challenging committee determines whether $Q$ or $R$ will represent the challenger committee to potentially introduce a bill to compete with the incumbent's policy (we call this chosen legislator the challenger). Second, the challenger chooses whether or not to introduce a competing bill, $B$. Third, nature moves and with probability $p$ refers $B$ to the challenger's committee (and to the incumbent's committee with probability 1-p). Finally, the incumbent and challenger choose to dispense with the bills choosing either a floor fight, a compromise, or to kill both bills.

We can characterize the utility functions for $Q$ and $R$ of the challenger committee as follows:

$U_{t}^{Q}=-\left|Q-x_{t}^{*}\right|+F^{Q}(o)+G^{Q}(l)+\delta E\left[-\left|Q-x_{t+1}^{*}\right|, F_{t+1}^{J}(o), G_{t+1}^{J}(l)\right]-C^{Q}(e)$

$U_{t}^{R}=-\left|R-x_{t}^{*}\right|+F^{R}(o)+G^{R}(l)+\delta E\left[-\left|R-x_{t+1}^{*}\right|, F_{t+1}^{J}(o), G_{t+1}^{J}(l)\right]-C^{R}(e)$ 
where $U_{t}^{j}$ is the utility to legislator $j, j \in\{Q, R\}$ in period $t, x_{t}^{*}$ is the equilibrium policy generated in period $t, F^{j}(o)$ is the benefit to oversight jurisdiction, $o, G^{j}(l)$ is the benefit to legislative jurisdiction, $l, \delta$ is the discount rate, and $C^{j}(e)$ is the cost, $C$, of effort, $e$, legislator $j$ exerts in writing a bill. We can re-index the legislator who is chosen to represent the challenger committee, in equilibrium, $T$. Thus, the utility functions for the incumbent, $J$, and the chosen challenger, $T$, can be reduced to:

$$
\begin{aligned}
& U_{t}^{J}=-\left|J-x_{t}^{*}\right|+F^{J}(o)+G^{J}(l)+\delta E\left[-\left|J-x_{t+1}^{*}\right|, F_{t+1}^{J}(o), G_{t+1}^{J}(l)\right]-C^{J}(e) \\
& U_{t}^{T}=-\left|T-x_{t}^{*}\right|+F^{T}(o)+G^{T}(l)+\delta E\left[-\left|T-x_{t+1}^{*}\right|, F_{t+1}^{J}(o), G_{t+1}^{J}(l)\right]-C^{T}(e)
\end{aligned}
$$

where $U_{t}^{i}$ is the utility to committee $i, i \in\{J, T\}$ in period $t$, and all remaining terms are as before. Recall that eq (4) is just the winner of the subgame between $Q$ and $R$ in eq (1) and eq (2). The first term of this utility function is the benefit that the committee (legislator) obtains from the equilibrium policy that will be passed. Committees (legislators) receive positive benefit the closer the policy outcome is to their ideal point. The second term is the discounted benefit obtained by the committee (legislator) from oversight jurisdiction, $\partial U_{t}^{i}(.) / \partial o>0$. The third term is the legislative jurisdiction a committee (legislator) has. Note that the benefits to the two committees are zero-sum - any gain in jurisdiction by one committee is a loss by a second committee (however, this is not the case for legislator that sit on the same committee).

In the fight between committees, we assume that the incumbent committee, $J$, has all the jurisdictional power, while the challenger committee, $T$, has none. This maps into policy $A$ in Figure 1. Normalizing this, we say that $G^{J}(l)=1, G^{T}(l)=0$ at the outset and create a bound for 
all time periods such that $G^{i}(l) \in[0,1]$. So if the challenger bill is referred to $J$, there is no change in utility to either committee. However, if the challenger bill is referred to $T$, then $J$ loses utility and $T$ gains that same amount of utility, so that $-\partial U_{t}^{T}(.) / \partial l=\partial U_{t}^{J}(.) / \partial l<0$.

The fourth term is the discounted expected payoff to the committee (legislator) of waiting until the next congress to enact policy, and is a function of the policy outcome in the next period and both jurisdictional outcomes. Finally, there is a cost to bill introduction, and that is encapsulated in $C^{i}(e)$, such that the incumbent committee has lower marginal cost in writing a bill than all potential challengers $\partial C^{T}(e) / \partial e^{>} \partial C^{J}(e) / \partial e$, but all challengers do not have the same marginal costs. This will induce the incumbent committee to introduce bills before the challenger will, ceteris paribus.

We can now discuss the first hypothesis of attenuation. There are two ways to analyze it. A simple and general way is to examine the utility function of the challenger. Recognize that the challenger can maintain the same utility levels if she gets less jurisdiction (second and third term) and more policy (first term). That is, the challenger is willing to trade jurisdiction for policy.

An alternative way to examine this is to apply it to the case being analyzed. We leave the challenger selection process aside for now and assume the best challenger has been selected. In the model, an incumbent committee member, $J$, proposes a bill that is referred to the incumbent committee (equivalent an issue in the position $A$ in Figure 1). The challenger committee member, $T$, can choose either to introduce a bill at cost, $C^{T}(e)$, or not introduce a bill. If there is no bill introduction, then the equilibrium policy outcome is the incumbent's policy position, provided is closer to the median voter, $M$, than the status quo, $F$, is to $M$, will become policy. 
If the challenger does introduce a bill, there is a probability, $p$, that this bill will be referred by the Parliamentarian to the challenger committee, will be pivotal in the behavior of committees. If the bill is introduced to the incumbent's committee, the equilibrium is the same as the case above (when there is no challenger bill).

If the second bill is referred to the challenger committee, the challenger committee has obtained some amount of jurisdictional benefit because the Parliamentarian now recognizes $T$ as a legitimate source of legislative jurisdiction over the issue. Conversely, $J$ loses some jurisdictional benefit, because formerly its legislative jurisdiction was unchallenged.

With two bills in two committees, there are three possible outcomes. First, both bills could come to the floor and a floor fight would ensue, the costs to the majority party are very high (e.g. campaign finance reform), and we assume the Speaker, through his gate-keeping capabilities, will kill both bills. This would be equivalent to a second outcome- the leadership will kill both bills and the status quo will persist until the next year, when there is a possibility to introduce bills again.

To consider the effects of jurisdictional outcomes on policy, let us consider extreme effects of the bill referral process. Let us assume the probability of a second bill referral to the challenger committee, $T$, is $p=1$. First, recognize that that even if no policy passes, $T$ is better off and $J$ is worse off, for reasonable bill introduction costs $C^{T}(e)$. This is because by merely having the second bill referred to $T$, the challenger gains some legislative jurisdiction over the issue and $J$ loses some legislative jurisdiction over the issue. Second, on the policy-making front, the incumbent will introduce a bill so as to maximize its expected utility. In order to do this, the incumbent must introduce bill $C$ so that the challenger is no worse off than the compromise policy solution plus the expected jurisdictional gains it would make (minus the costs 
of bill introduction) from introducing another bill. As the probability that $T$ receives a second bill increases, the incumbent is willing to introduce a bill closer to $T$ 's ideal point. The equilibrium policy when there is jurisdictional conflict will be on the interval $\left[T, F^{\prime}\right]$ where $F^{\prime}$ is the same distance from $F$ to $T$, but positioned on the opposite side of $T$ than is $F$. This is a form of compromise — offering a more moderate policy position to induce no challenge from a potential competitor. ${ }^{1}$ This provides the intuition for Hypothesis 1. Thus, the compensation required for the jurisdictional gain moves the policy closer to $T$; higher cost moves the equilibrium away from $T$. The higher $T$ values jurisdiction, the closer is equilibrium policy to $F$ '.

We can now append the challenger selection process. In order to achieve sub-game perfection in the full game, we must know what is the Nash equilibrium in the first stage. It is clear that a Nash equilibrium strategy for the challenger committee is to choose a challenging legislator who generates the most policy compromise. That is going to be the legislator who obtains the most utility from challenging. The incumbent's equilibrium policy offer is as close to $T$ as is necessary to stop a jurisdictional challenge. Both the incumbent and the challengers have no incentive to move off their strategies, given the other's strategy. Hence, we have a Nash equilibrium in the first stage. Thus, a complete characterization of Hypothesis 1 is that

\footnotetext{
${ }^{1}$ In a one period game (without expectations), there will always be compromise, enforced by the Speaker's gatekeeping power. However, politicians create policy today in the shadow of the future. If there is full information of these expectations in the next period, compromise is still reached. This is because both committees know the expectations about the outcome of the legislative game in the next period, and can factor this into the compromise they frame in this period. However, if there is uncertainty, and information is private, then compromise may be elusive. Assume each committee makes a private, unbiased assessment of its future prospects in the next congress, with some error, $\varepsilon \sim \mathrm{N}\left(0, \sigma^{2}\right)$ (Priest and Klein 1984). If both sides have negative errors (private pessimistic draws about their prospects for the next period) then there will be more room for compromise in the current period. If both sides have positive errors (private optimism about their possibilities in the next period), then there will be no compromise and both bills will die. If one side is optimistic and one side is pessimistic, then it is the relative optimism and pessimism that will matter. With respect to the two focal bills, both bills were killed in the Rules Committee by the House leadership. Both sides were optimistic about their chances in the next Congress, and this resulted in neither side accepting compromise. Thus, even though either bill would likely have made the median voter of the House floor better off than Feist, both bills died. A more complete account can be found in Author (2002).
} 
challenger forces the incumbent's attenuation to a point as close to $T$ as possible with the selection of the challenging legislator.

While we cannot identify precise who this legislator is theoretically, we can examine the comparative statics. These comparative statics are the same as they are for the fight between the two committees, as outlined earlier in the appendix. Specifically, a legislator on the competing committee is more likely to be selected the more she gains from jurisdiction, the more she gains from policy outcomes, and the more she values the future. This then leads us to Hypothesis 2. 